\title{
Candida Glabrata Infection in a Burn Patient
}

\author{
D Ceren Çetin, ${ }^{1}$ (1) Ayşe Karaaslan,, (D) Murat Dereli, ${ }^{2}$ \\ (1) Yasemin Akın, ${ }^{1}$ (1) Halise Cankılıç, ${ }^{3}$ (ㅁ Gaye Filinte ${ }^{4}$
}

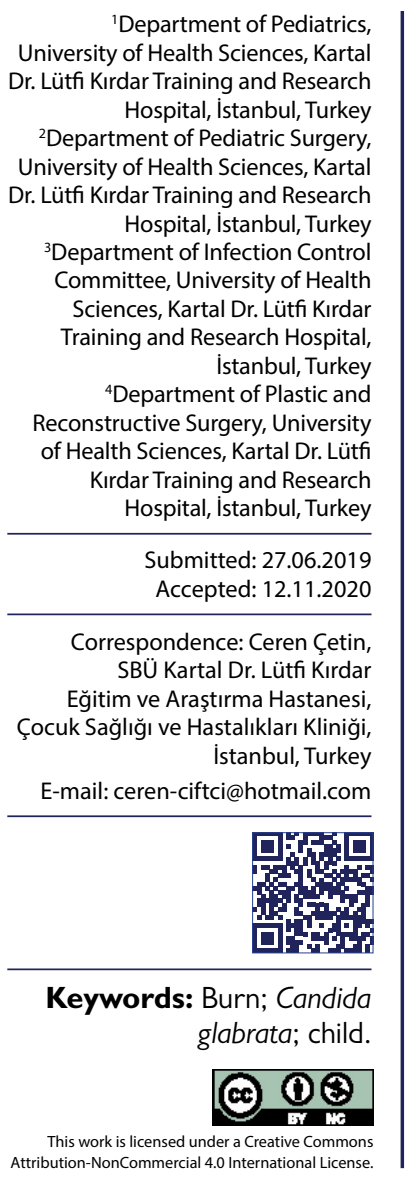

\begin{abstract}
Candida species are found in the normal human flora; however, predisposing factors, such as immunosuppression, intensive care unit stay, and catheter use, may cause progression to disease. Candida glabrata is a rare, but potentially life-threatening, fungal infection. This report describes the case of a 14-month-old male patient who developed Candida glabrata candidemia during hospitalization in the burn ward. The patient was admitted to the hospital with second-degree scald burns comprising $9.5 \%$ of the total body surface area. A fever was observed on the third day of hospitalization and empiric intravenous piperacillin-tazobactam therapy was initiated. A blood culture revealed no microorganism. Fluconazole was added to the patient's therapy on the fifth day of treatment due to yeast reported on a blood culture taken after a recurrence of fever. Laboratory results indicated that the yeast was Candida glabrata and treatment with caspofungin was implemented. A control blood culture was sterile. Candida glabrata is a rare fungal pathogen, however, it can cause severe infection and is resistant to azoles. The classic risk factors of immunosuppression, intensive care unit admission, or catheter administration were not present in this case, yet it should be kept in mind that burn patients are secondarily immunosuppressed and prone to severe infections.
\end{abstract}

\section{INTRODUCTION}

Candidemia is a serious infection with a mortality rate of $30 \%$ in children and $50 \%$ in adults. ${ }^{[1]}$ Risk factors include admission to the intensive care unit, parenteral nutrition, a central venous catheter, and underlying immunosuppression.

Worldwide, Candida albicans and Candida parapsilosis are the most common species of Candida that cause infection in children, while in adults, Candida albicans, Candida glabrata, Candida parapsilosis, Candida tropicalis and Candida krusei are the most common. ${ }^{[2,3]}$ Study data from Turkey indicate that Candida parapsilosis is the most fre- quently seen, with a rate of $61.3 \%$, followed by Candida albicans (27.3\%), Candida tropicalis (6.3\%), Candida lusitaniae (2\%), Candida glabrata (I.2\%) and Candida dubliniensis $(0.4 \%){ }^{[4]}$

It has been established that the rate of infection with non-albicans species has increased in recent years. ${ }^{[3]}$ According to United States data, Candida glabrata is the cause of $20 \%$ to $30 \%$ of candidemia cases. Candida glabrata is becoming increasingly important due to its general resistance to azoles and increasing resistance to echinocandins. ${ }^{[5]}$

This article describes the rare case of a 14-month-old male patient with Candida glabrata candidemia who was hospitalized in the burn unit. 


\section{CASE REPORT}

A 14-month-old male was presented at the burn unit due to scald burns. The patient was admitted with second-degree burns on both lower extremities, comprising $9.5 \%$ of the total body surface area. A fever was observed on the third day of admission, and test results indicated a leukocyte count of $8700 / \mathrm{mm}^{3}$, a platelet count of $186,000 /$ $\mathrm{mm}^{3}$, a C-reactive protein (CRP) level of $11.5 \mathrm{mg} / \mathrm{L}$ (normal: $0-3.5 \mathrm{mg} / \mathrm{L}$ ), and a procalcitonin value of $0.043 \mu \mathrm{g} / \mathrm{L}$ (normal: $<0.1 \mu \mathrm{g} / \mathrm{L}$ ). Empirical piperacillin-tazobactam intravenous treatment was initiated once urine and blood cultures were obtained. Upon detection of Escherichia coli growth of $>100000 \mathrm{CFU} / \mathrm{mL}$ in the urine culture, the treatment was replaced with intravenous ertapenem based on the antibiogram sensitivity. No growth was detected in a simultaneous blood culture. A fever developed once again on the fifth day of treatment, and testing revealed a leukocyte count of $11,300 / \mathrm{mm}^{3}$, a platelet count of $156,000 / \mathrm{mm}^{3}$, a CRP level of $22.5 \mathrm{mg} / \mathrm{L}$ (normal: $0-3.5$ $\mathrm{mg} / \mathrm{L}$ ), and a procalcitonin value of $0.2 \mu \mathrm{g} / \mathrm{L}$ (normal: $<0.1$ $\mu \mathrm{g} / \mathrm{L}$ ). Intravenous fluconazole treatment was added for yeast pre-growth reported in a blood culture performed due to the fever. Fluconazole was exchanged for caspofungin when it was determined that the yeast growth was Candida glabrata. An antifungal sensitivity test showed resistance to fluconazole and sensitivity to caspofungin, and the new treatment protocol was continued. The results of echocardiography, abdominal-urinary ultrasonography, and an eye examination performed to assess for fungal dissemination were normal. No growth was detected in a urine culture or a blood culture taken at the $48^{\text {th }}$ hour of antifungal treatment. There was no fever 24 hours after the antifungal treatment was initiated. Ertapenem treatment was maintained for 10 days and antifungal treatment for 14 days.

\section{DISCUSSION}

In the United States, some 120,000 pediatric patients present at emergency clinics for burns each year. ${ }^{[6]} \mathrm{On}$ average, $60 \%$ to $80 \%$ of the burns seen in young children are scald burns, and the mortality rate is below $2 \% .^{[7,8]}$ Globally, more than 300,000 patients die each year due to burns. [9] One of the most important causes of mortality is infection. In burn patients, susceptibility to infection increases because the skin integrity, which is the first barrier to infection, has been lost and as the wound area grows, the chance of the introduction of microorganisms increases. ${ }^{[10]}$ In addition, the inflammatory process continues while the wound area remains open. Burn patients are vulnerable to microorganisms that are common infectious agents, as well as other factors that are ordinarily less virulent, due to an impaired immune system. Ramirez-Blanco et al. ${ }^{[9]}$ reported that among a group of 402 burn patients, including adults and children, $88.5 \%$ of the agents causing infection were bacteria and $11.5 \%$ were fungi. Although Candida albicans is the most common causative agent, a growing mortality rate has been associated with Candida tropicalis and Candida krusei. ${ }^{[1,12]}$ Candida glabrata has been reported in burn patients, though less frequently than Candida albicans. Gupta et al. ${ }^{[13]}$ reported that in 220 burn patients, Candida albicans ( $45 \%$ ) was the most common, followed by Candida tropicalis (33\%), and Candida glabrata (13.5\%).

An invasive Candida infection has a very high mortality rate. Therefore, rapid diagnosis and treatment are important. Isolation in a blood culture is still the most important and frequently used diagnostic method. Useful knowledge when planning a candidemia treatment regimen includes any previous exposure to azole or echinocandins, intolerance to any antifungal drug, the predominant Candida type in the hospitalization unit, and the involvement of other organs, such as the central nervous system or the heart. According to the most recent Infectious Diseases Society of America (IDSA) guideline data (2016), the first treatment option for candidemia should be echinocandins. If the Candida glabrata is found to be susceptible to fluconazole, it has been reported that it can be used as subsequent maintenance therapy. ${ }^{[14]}$ However, according to Clinical and Laboratory Standards Institute data, the minimum inhibitory concentration (MIC) value of Candida glabrata for fluconazole sensitivity has not been conclusively defined, but organisms with a MIC value of $\leq 32 \mu \mathrm{g} / \mathrm{mL}$ were classified as susceptible dose-dependent, and those with a MIC value $>64 \mu \mathrm{g} / \mathrm{ml}$ were considered resistant. ${ }^{[15]}$

Echinocandins have demonstrated significant fungicidal activity for most Candida species, and most agents have been shown to yield $70 \%$ to $75 \%$ successful results. ${ }^{[1,16,17]}$ Many experts prefer echinocandins as the first choice due to fluconazole resistance, the safety profile, and a low record of interaction with other drugs. ${ }^{[16,18]}$ When the first Candida growth was reported in our patient, intravenous fluconazole treatment was considered appropriate because his general condition was good, he was not hospitalized in the intensive care unit, he did not have a central catheter, he was not receiving total parenteral treatment, and because Candida albicans was the most common Candida species in our hospital; however, we substituted echinocandin (caspofungin) treatment when non-albicans reproduction was reported. Treatment with caspofungin was continued when it was reported to be resistant to Candida glabrata and fluconazole and susceptible to caspofungin.

Chow et al. ${ }^{[19]}$ reported that interventions performed in intensive care, gastrointestinal procedures, enteric bacteremia, the number of hemodialysis days, total parenteral nutrition, and the number of erythrocyte transfusions were risk factors for bloodstream infections developing with non-albicans Candida. Our patient did not have these risk factors; however, since he was a burn patient, a daily dressing change was performed by the surgical department and skin debridement was to be performed as necessary. It was decided that these procedures could also be considered invasive and were evaluated as a risk factor.

The most important risk factor for patients with candidemia may be the presence of a central venous catheter, 
as it has been reported in as many as $70 \%$ of cases. ${ }^{[19,20]}$ Eschenauer et al. ${ }^{[2]]}$ demonstrated a direct relationship between the presence of a catheter and death in 127 patients with Candida glabrata bloodstream infection. As stated in the IDSA guidelines, if feasible, a central venous catheter should be removed as soon as possible in patients who develop candidemia. ${ }^{[14]} \mathrm{Karadag}-O$ ncel et al. ${ }^{[22]}$ conducted research in Turkey examining 248 pediatric cases with candidemia episodes and found that mortality decreased with the removal of the central venous catheter. Our patient did not have a central catheter, but our routine protocol is to remove a central catheter if candidemia develops.

This patient did not have the risk factors of intensive care unit admission, use of a central catheter, or a previous diagnosis of immunodeficiency. Cleaning the dead tissue and debridement when necessary was an effective method of preventing infection. However, debridement should also be considered an invasive procedure. It is also important to remember that burn patients are secondarily immunosuppressed and susceptible to severe infection. Accurate and rapid diagnosis of Candida species that can cause a systemic infection in a burn patient and appropriate, early antifungal treatment can have a significant impact on mortality.

\section{Informed Consent}

Written informed consent was obtained from the patient's parent for publishing the case report and accompanying images.

Peer-review

Internally peer-reviewed.

Authorship Contributions

Concept: C.C.; Design: C.C., A.K.; Supervision: C.C., A.K.; Analysis: C.C., A.K., Y.A.; Literature search: C.C., A.K., Y.A., M.D., H.C., G.F.: Writing: C.C.; Critical revision: C.C., A.K.

Conflict of Interest

None declared.

\section{REFERENCES}

1. Tavanti A, Davidson AD, Gow NA, Maiden MC, Odds FC. Candida orthopsilosis and Candida metapsilosis spp. nov, to replace Candida parapsilosis groups II and III. J Clin Microbiol 2005;43:284-92.

2. Nucci M, Queiroz-Telles F, Alvarado-Matute T, Tiraboschi IN, Cortes J, Zurita J, et al. Latin American invasive mycosis network. Epidemiology of candidemia in Latin America: a laboratory-based survey. PLoS One 2013;8:e59373. [CrossRef]

3. García-Rodríguez J, Cantón E, Pemán J, Alvarez M, Ezpeleta G, Gómez-Nieto A, et al. Age group, geographical incidence and patterns of antifungal susceptibility of Candida species causing candidemia in the Spanish paediatric population. Enferm Infecc Microbiol Clin 2013;31:363-8. [CrossRef]

4. Kara A, Devrim İ, Meșe T, Bayram N, Yllmazer M, Gülfidan G. The frequency of infective endocarditis in candida bloodstream infec- tions: a retrospective study in a child hospital. Braz J Cardiovasc Surg 2018;33:54-8. [CrossRef]

5. Pfaller MA, Diekema DJ. Epidemiology of invasive candidiasis: a persistent public health problem. Clin Microbiol Rev 2007;20:133-63.

6. National Center for Injury Preventions and Control. Data and statistics (wisqars). Available at: www.cdc.gov/injury/wisqars/index.html. Accessed Oct 30, 2015.

7. Tse T, Poon CH, Tse KH, Tsui TK, Ayyappan T, Burd A. Paediatric burn prevention: an epidemiological approach. Burns 2006;32:22934. [CrossRef]

8. Saeman MR, Hodgman EI, Burris A, Wolf SE, Arnoldo BD, Kowalske KJ, et al. Epidemiology and outcomes of pediatric burns over 35 years at Parkland Hospital. Burns 2016;42:202-8. [CrossRef]

9. Ramirez-Blanco CE, Ramirez-Rivero CE, Diaz-Martinez LA, SosaAvila LM. Infection in burn patients in a referral center in Colombia. Burns 2017;43:642-53. [CrossRef]

10. Greenhalgh DG. Sepsis in the burn patient: a different problem than sepsis in the general population. Burns Trauma 2017;5:23.

11. Alangaden GJ. Nosocomial fungal infections: epidemiology, infection control, and prevention. Infect Dis Clin North Am 2011;25:201-25.

12. Hope W, Morton A, Eisen DP. Increase in prevalence of nosocomial non-Candida albicans candidaemia and the association of Candida krusei with fluconazole use. J Hosp Infect 2002;50:56-65. [CrossRef]

13. Gupta N, Haque A, Lattif AA, Narayan RP, Mukhopadhyay G, Prasad R. Epidemiology and molecular typing of Candida isolates from burn patients. Mycopathologia 2004;158:397-405. [CrossRef]

14. Pappas PG, Kauffman CA, Andes DR, Clancy CJ, Marr KA, Ostrosky-Zeichner L, et al. Clinical practice guideline for the management of candidiasis: 2016 update by the Infectious Diseases Society of America. Clin Infect Dis 2016;62:e1-e50. [CrossRef]

15. Clinical and Laboratory Standards Institute. Reference method for broth microdilution antifungal susceptibility testing of yeasts. 4th informational supplement. CLSI M27-S4. Pennsylcania: Clinical and Laboratory Standards Institute; 2012.

16. Pappas PG, Rotstein CM, Betts RF, Nucci M, Talwar D, De Waele JJ, et al. Micafungin versus caspofungin for treatment of candidemia and other forms of invasive candidiasis. Clin Infect Dis 2007;45:883-93.

17. Betts RF, Nucci M, Talwar D, Gareca M, Queiroz-Telles F, Bedimo $\mathrm{RJ}$, et al. A multicenter, double-blind trial of a high-dose caspofungin treatment regimen versus a standard caspofungin treatment regimen for adult patients with invasive candidiasis. Clin Infect Dis 2009;15;48:1676-84. [CrossRef]

18. Kohno S, Izumikawa K, Yoshida M, Takesue Y, Oka S, Kamei K, et al. A double-blind comparative study of the safety and efficacy of caspofungin versus micafungin in the treatment of candidiasis and aspergillosis. Eur J Clin Microbiol Infect Dis 2013;32:387-97. [CrossRef]

19. Chow JK, Golan Y, Ruthazer R, Karchmer AW, Carmeli Y, Lichtenberg DA, et al. Risk factors for albicans and non-albicans candidemia in the intensive care unit. Crit Care Med 2008;36:1993-8. [CrossRef]

20. Wagner M, Bonhoeffer J, Erb TO, Glanzmann R, Häcker FM, Paulussen M, et al. Prospective study on central venous line associated bloodstream infections. Arch Dis Child 2011;96:827-31. [CrossRef]

21. Eschenauer GA, Carver PL, Patel TS, Lin SW, Klinker KP, Pai MP, et al. Survival in patients with candida glabrata bloodstream infection is associated with fluconazole dose. Antimicrob Agents Chemother 2018;62:e02566-17. [CrossRef]

22. Karadag-Oncel E, Kara A, Ozsurekci Y, Arikan-Akdagli S, Cengiz $\mathrm{AB}$, Ceyhan $\mathrm{M}$, et al. Candidaemia in a paediatric centre and importance of central venous catheter removal. Mycoses 2015;58:140-8. 


\section{Yanık Hastasında Gelişen Candida Glabrata Enfeksiyonu}

Candida türleri normal florada bulunmaktadırlar ancak, bağışılık sisteminin baskılanması, kateter kullanımı ve yoğun bakım ünitesinde yatmak gibi altta yatan hazırlayıcı faktörler sonucunda hastalık gelişimine neden olabilmektedirler. Candida glabrata çocuklarda hayatı tehdit eden ve nadir görülen mantar enfeksiyonudur. Bu yazıda, yanık ünitesinde yatan Candida glabrata kandidemisi gelişen 14 aylık hasta sunulmuştur. On dört aylık erkek çocuk yanık servisinde \%9.5 oranında ikinci derece kaynar su ile haşlanma yanığı nedeniyle yatırıldı. Hastanın yatışının üç gününde ateş olması üzerine ampirik piperasillin-tazobaktam intravenöz tedavisi başlandı. Kan kültüründe üreme saptanmadı. Tedavinin beşinci gününde tekrar ateşi olması nedeniyle alınan kan kültüründe maya ön üreme bildirilmesi üzerine tedaviye intravenöz flukonazol eklendi. Üremenin Candida glabrata olması üzerine tedavi caspofungine olarak değiştirildi. Kontrol kan kültürde üreme saptanmadı. Candida glabrata nadir görülen ciddi enfeksiyon tablosuna sebep olabilen ve azollere dirençli olan, bir mantar türüdür. Bu olgumuzda bilinen bir immün yetersizlik tanısı, yoğun bakım yatışı ya da santral kateter kullanımı yoktu. Ancak yanık hastalarının da sekonder immünsüprese oldukları ve ciddi ve nadir enfeksiyonlara yatkın oldukları unutulmamalıdır.

Anahtar Sözcükler: Candida glabrata; çocuk; yanık. 